\title{
GOD'S PROVIDENCE AND THE PLURALITY OF RELIGIONS
}

\author{
VOJTĚCH N OVOT N Ý
}

\begin{abstract}
The 'Document on Human Fraternity for World Peace and Living Together', co-signed on 4 February 2019 by Pope Francis and the Grand Imam of Al Azhar, Ahmad Al-Tayeb, states: 'The pluralism and the diversity of religions, colour, sex, race and language are willed by God in His wisdom, through which He created human beings.' The article presents the starting points of correct hermeneutics of this statement. It points out that it is a positive reformulation of the anti-discrimination human rights declarations, which list the criteria according to which people cannot be discriminated. It shows the compatibility of the statement with the Quran, which presupposes a plurality of successive and graded revelations of God and religions: Judaism, Christianity, and Islam. It then represents the reactions with which Catholic theologians responded to the statement: the accusation of the Pope of heresy; the claim that while God's creative will has instilled a natural religion in human beings, it does not positively seek a plurality of religions; the claim that non-Christian religions are an evil by which God allows to achieve greater good; the claim that all religions are wanted by God's Providence in what is true, good, and beautiful in them as the preparation for the salvation of man in the encounter with Christ. In the end, it discusses the idea of St. John Paul II, who, for several years before the creation of the Abu Dhabi declaration, combined this last idea with the work of the Holy Spirit.
\end{abstract}

Keywords:

Document on Human Fraternity; Hermeneutics; Islam; Christianity

DOI: $10.14712 / 23363398.2021 .3$

$\mathrm{T}$

he 'Document on Human Fraternity for World Peace and Living Together', co-signed on 4 February 2019 by Pope Francis and the Grand Imam of Al Azhar, Ahmad Al-Tayeb, is on a closer look very 
complex with its genesis, content, goals and interpretive contexts. ${ }^{1}$ As a theme of my paper, I have chosen one, but a very important passage, which reads as follows:

Freedom is a right of every person: each individual enjoys the freedom of belief, thought, expression and action. The pluralism and the diversity of religions, colour, sex, race and language are willed by God in His wisdom, through which He created human beings. This divine wisdom is the source from which the right to freedom of belief and the freedom to be different derives. Therefore, the fact that people are forced to adhere to a certain religion or culture must be rejected, as too the imposition of a cultural way of life that others do not accept. ${ }^{2}$

I would like to approach this statement by reflecting on some of the hermeneutical starting points for working with the 'Document on Human Fraternity'; then, I will focus on the literary sources of the above-mentioned statement and try to clarify in what sense it is in line with Islam. After that, I will deal with the question of its conformity with Christianity by, firstly, pointing out the negative reactions among Catholics and, secondly, presenting an acceptable Catholic theological interpretation.

1 Srov. Fratellanza (Roma: La Civiltà Cattolica, 2020); Domenico Marafioti, 'Documento sulla Fratellanza umana: una lettura ragionata,' Rassegna di Teologia 60, no. 2 (2019): 235-268; Giacomo Costa, 'Le religioni e il coraggio dell'alterità: la Dichiarazione congiunta di Abu Dhabi,' Aggiornamenti Sociali 70, no. 3 (2019): 181-188.

2 Pope Francis, 'Document on Human Fraternity for World Peace and Living Together,' The Holy See, last modified 4. February 2019, https://cutt.ly/Olzn6aZ. According to 'Bolletino Sala stampa della Santa Sede' it is necessary to consider the Italian and the Arabic version as the original text. They are also the source of this article. As concerns Arabic, I am grateful for the help of Mgr. Mlada Mikulicová, Ph.D.

'La libertà è un diritto di ogni persona: ciascuno gode della libertà di credo, di pensiero, di espressione e di azione. Il pluralismo e le diversità di religione, di colore, di sesso, di razza e di lingua sono una sapiente volontà divina, con la quale Dio ha creato gli esseri umani. Questa Sapienza divina è l'origine da cui deriva il diritto alla libertà di credo e alla libertà di essere diversi. Per questo si condanna il fatto di costringere la gente ad aderire a una certa religione o a una certa cultura, come pure di imporre uno stile di civiltà che gli altri non accettano.'

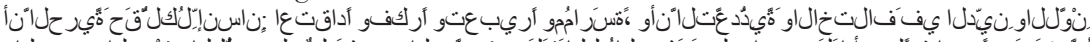

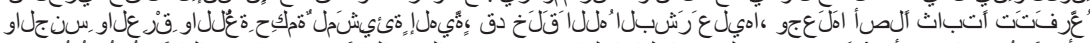

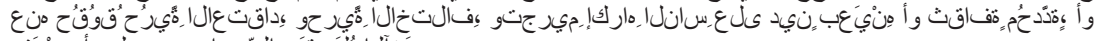

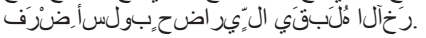




\section{Hermeneutical Starting Points}

The correct interpretation of the individual passages has to consider the authorship of the text, its literary type, intentions, and sources.

The 'Document on Human Fraternity' is a shared text ${ }^{3}$ by which the representatives of two world religions (if we may in this way refer to the Grand Imam of the University of Cairo alongside the Bishop of Rome) jointly address their fellow believers and the world in an effort to express such religious attitudes and social as well as cultural intentions which would be a manifestation of human fraternity and an instrument of joint efforts for world peace and peaceful coexistence. It is a manifestation of religious diplomacy as the document states that both parties 'declare the adoption of a culture of dialogue as the path; mutual cooperation as the code of conduct; reciprocal understanding as the method and standard'.

Such a text cannot be criticised for what it does not contain in terms of one religion or another because the common text of two religions does not include the details of only one party and consciously refrains from injuring the other and thus jeopardising the purpose of the document. On the contrary, the use of religious themes is placed at the service of common goals in such a way as to maximise interfaces by indicating identical or similar doctrinal contents and religious attitudes, i.e. those which can be described by the same terms even if each party attaches somewhat different meaning to them; these differences, however, are deliberately unpronounced. ${ }^{4}$

Therefore, it would be detrimental to this diplomatic document if we considered it to represent the magisterial teaching of the Pope or the Catholic Glaubensmanifest. ${ }^{5}$ It is not a manifestation of the extraordinary or ordinary magisterium of the Catholic Church, which the Catholics must accept as 'divine and Catholic truth' (Lumen gentium 25;

\footnotetext{
Giacomo Costa, 'Le religioni e il coraggio dell'alterità,' 183.

4 Vincenzo Pinto goes even further: Giovanni Marcotullio, 'Se Gesù è l'unico salvatore, come può Dio aver voluto le altre religioni?,' Aleteia, last modified 11 February 2019, https://cutt.ly/CIS1woV.: 'la Dichiarazione [...] non solo non potrà contenere esplicite confessioni di fede cristologica/trinitaria, ma dovrà essere giudicata anzitutto per cosa è riuscita a far firmare alla controparte. [...] È ovvio che un simile documento "d'unione" sia per sua natura un testo compromissorio, i cui effetti collaterali sono anzitutto il risultare compromettente per le due parti in causa.'

5 Cf. Gerhard Ludwig Müller, 'Glaubensmanifest Euer Herz lasse sich nicht verwirren,' accessed 29 February 2020, http://document.kathtube.com/47411.pdf.
} 
Dei verbum 10). Nor is it a Christian theological treatise. Therefore, the document cannot be interpreted according to the demands of factual completeness and coherence of argument, which are necessary as concerns, for example, the declaration of the Second Vatican Council Nostra aetate on the Church's relationship to non-Christian religions or the declaration of the Congregation for the Doctrine of the Faith Dominus Iesus on the uniqueness and saving universality of Jesus Christ and the Church.

On the other hand, it is not even a document that expresses only the private opinion of the Pope, and that would not concern the believers entrusted to his pastoral care. Therefore, the document can be rightfully expected not to contain anything that would be in direct conflict with the Catholic faith. In addition, something similar has to be applied to the other party's faith. It is thus more of a kind of doctrinal minimum than a maximum. This minimum is to be interpreted by each party in the light of the whole of its faith, but with the preservation of the whole intention of the document. However, even in this regard, it is not entirely easy since what is contained in the text in the form of a declaration or proposition should be reflected by each addressee in a proper way, with some kind of self-questioning. In this sense, it can be a text of asymmetric practical consequences. ${ }^{6}$

\section{Sources}

Another necessary condition for the correct interpretation of the relevant passage is the attention to its sources. All the known interpretations of the Abu Dhabi document have overlooked an important fact - the fact that the statement under discussion is a paraphrase of anti-discrimination human rights declarations, whether those bound to

6 One of the commentators, for example, rightly remarked that if the 'Document on Human Fraternity' postulates 'freedom of religion, thought, expression, and action,' then it does not directly mention freedom to change religion and does not explicitly support the right of Muslims to convert to another religion, which Islamic law punishes with death. However, it can be read to support such a right. In this respect, the document sounds like an Islamic declaration Nostra aetate and the claim that God wants religious pluralism is a direct and provocative response to the conservative elements of Sunni Islam (such as Salafism), which are only interested in Islam's triumph over other religions in the form of proselytism or holy war. Gabriel Said Reynolds, 'After Abu Dhabi,' Commonweal, accessed 27 March 2019, https://cutt.ly/JIS19Ks. 
the Euro-Atlantic area or those created in the Arab world. ${ }^{7}$ As evidence, we can use the following comparison:

\begin{tabular}{|c|c|}
\hline $\begin{array}{l}\text { Document } \\
\text { on Human } \\
\text { Fraternity } \\
\text { for World Peace } \\
\text { and Living } \\
\text { Together (2019) }\end{array}$ & $\begin{array}{l}\text { Freedom is a right of every person: each individual } \\
\text { enjoys the freedom of belief, thought, expression and } \\
\text { action. The pluralism and the diversity of religions, } \\
\text { colour, sex, race and language are willed by God in } \\
\text { His wisdom, through which He created human beings. } \\
\text { This divine wisdom is the source from which the right } \\
\text { to freedom of belief and the freedom to be different } \\
\text { derives. Therefore, the fact that people are forced } \\
\text { to adhere to a certain religion or culture must be } \\
\text { rejected, as too the imposition of a cultural way of life } \\
\text { that others do not accept. }\end{array}$ \\
\hline $\begin{array}{l}\text { Universal } \\
\text { Declaration } \\
\text { of Human Rights } \\
\quad(1948) \\
\text { art. 2, para. } 1\end{array}$ & $\begin{array}{l}\text { Everyone is entitled to all the rights and freedoms set } \\
\text { forth in this Declaration, without distinction of any } \\
\text { kind, such as race, colour, sex, language, religion, } \\
\text { political or other opinion, national or social origin, } \\
\text { property, birth or other status. }\end{array}$ \\
\hline art. 18 & $\begin{array}{l}\text { Everyone has the right to freedom of thought, } \\
\text { conscience and religion; this right includes freedom to } \\
\text { change his religion or belief, and freedom, either alone } \\
\text { or in community with others and in public or private, } \\
\text { to manifest his religion or belief in teaching, practice, } \\
\text { worship and observance. }\end{array}$ \\
\hline $\begin{array}{c}\text { Universal } \\
\text { Islamic } \\
\text { Declaration } \\
\text { of Human Rights } \\
\text { (1981) } \\
\text { art. } 3\end{array}$ & $\begin{array}{l}\text { All persons are equal before the Law and are entitled } \\
\text { to equal opportunities and protection of the Law. All } \\
\text { persons shall be entitled to equal wage for equal work. } \\
\text { No person shall be denied the opportunity to work or } \\
\text { be discriminated against in any manner or exposed } \\
\text { to greater physical risk by reason of religious belief, } \\
\text { colour, race, origin, sex or language. }\end{array}$ \\
\hline
\end{tabular}

7 The documents are quoted according to the collection University of Minnesota: 'Human Right Library,' Human Rights Library, accessed 29 February 2020, http:// hrlibrary.umn.edu. For basic introduction, see, for example, Attilio Pisanò, I diritti umani come fenomeno cosmopolita: internazionalizzazione, regionalizzazione, specificazione (Milano: Giuffrè Editore, 2011), 110-134. 


\begin{tabular}{|c|c|}
\hline arts. $10,12,13$ & $\begin{array}{l}\text { The Qur'anic principle "There is no compulsion } \\
\text { in religion" shall govern the religious rights of } \\
\text { non-Muslim minorities. In a Muslim country } \\
\text { religious minorities shall have the choice to be } \\
\text { governed in respect of their civil and personal matters } \\
\text { by Islamic Law, or by their own laws. (...) Every person } \\
\text { has the right to express his thoughts and beliefs so } \\
\text { long as he remains within the limits prescribed by } \\
\text { the Law. (...) Every person has the right to freedom } \\
\text { of conscience and worship in accordance with his } \\
\text { religious beliefs. }\end{array}$ \\
\hline $\begin{array}{c}\text { Cairo } \\
\text { Declaration } \\
\text { on Human Rights } \\
\text { in Islam (1990) } \\
\text { art. } 1\end{array}$ & $\begin{array}{l}\text { All human beings form one family whose members } \\
\text { are united by submission to God and descent from } \\
\text { Adam. All men are equal in terms of basic human } \\
\text { dignity and basic obligations and responsibilities, } \\
\text { without any discrimination on the grounds of race, } \\
\text { colour, language, sex, religious belief, political } \\
\text { affiliation, social status or oilier considerations. True } \\
\text { faith is the guarantee for enhancing such dignity along } \\
\text { the path to human perfection. }\end{array}$ \\
\hline $\begin{array}{c}\text { Arab Charter } \\
\text { on Human Rights } \\
\text { (1994) } \\
\text { art. } 2\end{array}$ & $\begin{array}{l}\text { Each State party to the present Charter undertakes } \\
\text { to ensure that every individual located within its } \\
\text { territory and subject to its jurisdiction, shall have the } \\
\text { right to enjoy all the rights and freedoms recognised } \\
\text { in this [Charter], without distinction on the basis of } \\
\text { race, colour sex, language, religion, political opinion, } \\
\text { national or social origin, wealth, birth or other status, } \\
\text { and without any discrimination between men and } \\
\text { women. }\end{array}$ \\
\hline $\begin{array}{c}\text { Arab Charter } \\
\text { on Human Rights } \\
\text { (2004) } \\
\text { art. 3, letter a) }\end{array}$ & $\begin{array}{l}\text { Each State Party to the present Charter undertakes } \\
\text { to ensure to all individuals within its territory } \\
\text { and subject to its jurisdiction the right to enjoy } \\
\text { all the rights and freedoms recognised herein, } \\
\text { without any distinction on grounds of race, color, } \\
\text { sex, language, religion, opinion, thought, national or } \\
\text { social origin, property, birth or physical or mental } \\
\text { disability. }\end{array}$ \\
\hline
\end{tabular}




\begin{tabular}{|c|l|}
\hline Declaratio & The Church reproves, as foreign to the mind of Christ, \\
de Ecclesiae & any discrimination against men or harassment of \\
habitudine & them because of their race, color, condition of life, or \\
ad religiones & religion. \\
non-christianas \\
Nostra aetate \\
art. 5
\end{tabular}

Although there are different preconceptions behind the same or similar concepts, what has already been implied by the cited overview is that the chosen part of the 'Document on Human Fraternity' follows the diction of the anti-discrimination human rights declarations. It cites some categories that describe the differences between people without allowing these differences (religion, colour, gender, race, and language) to lead to inequality or discrimination against people as such.

However, the Abu Dhabi declaration changes the meaning of these statements. Where the Human Rights declarations negatively state that these differences are not a manifestation of inequality between people, and where the declaration of the Second Vatican Council Nostra aetate says that such discrimination is 'foreign to the mind of Christ' (art. 5), our document positively states that these differences are the expression of God's will in his creative wisdom. It provides a religious explanation of the origin of these differences and thus a rationale for why they are not a manifestation of inequality between people.

The second shift of the document compared to human rights declarations is that the list of differences between people is directly linked to the principle of freedom of religion, thought, expression, and action. Moreover, these differences between people, including the difference between religions, are derived from God's creative wisdom, which implies the freedom of religion as well as the condemnation of the imposition of religion and corresponding civilisation style.

It is to this affirmation of religious plurality and freedom of religion that the whole statement is directed. However, the question is whether positive religious reformulation of a negative human rights anti-discrimination norm is intellectually coherent and justified, in other words, whether the statement can be reconciled with Islam and Christianity and whether and how it will stand up to the question of truth. 


\section{Compliance with Islam?}

So is the statement that the plurality of religions is the result of a wise decision of the divine will in accordance with Islam? Probably yes, if a high representative of this faith stood up for it. For Islam, the pluralistic concept of religions wanted by God is inherent, and perhaps because of the authorial contribution of the Islamic side, the negative human rights anti-discrimination norm in the Abu Dhabi document has been reformulated in religious terms.

For example, the above-cited Arab Charter on Human Rights (1994, 2004) states in the preamble that it is composed 'pursuant to the eternal principles of brotherhood and equality among all human beings which were firmly established by the Islamic Shari'a and the other divinely-revealed religions'. As can be seen, human fraternity and equality are derived here from the plurality of religions revealed by God - as if the statement of the 'Document on Human Fraternity' we focus on was an echo of this passage.

However, on the part of Islam, the real root is, of course, the Quran. Not only does it explicitly state that the diversity of languages and colours is the work and sign of the Creator, ${ }^{8}$ but it also attributes to God the diversity of revelations and religions. It repeatedly declares the Jewish Torah and the Christian Jesus of the Gospels as God's revelation, which is confirmed, corrected, and overcome by the final revelation given to the Prophet Muhammad.

For example, the third Surah states that God 'has sent down to you the Book [the Quran] with the truth confirming what was [revealed] before it, and He had sent down the Torah and the Evangel before as guidance for mankind'. On the other hand, they claim that the only religion, according to God, is Islam $(3: 3-4,19)$. The Quran is well aware that Jews and Christians alike struggle to claim the exclusive truth of their faith and thus adds that it, in fact, belongs to Islam as much as it is a summary and transcendence of what was right in these religions (2: 111-113,120,136-137).

Islam is thus entitled to make the final decision about the truthfulness and correctness of religions. This decision is full of tensions. In

8 'Among His signs is the creation of the heavens and the earth, and the difference of your languages and colours. There are indeed signs in that for those who know' (30:22). Quoted according to the database: 'The Quran: Online Translation and Commentary,' accessed 29 February 2020, http://al-quran.info. 
various parts of the Quran, the Jew and the Christian are called 'unbelievers' (käfir), and this is also expressed in militant texts and their violent interpretations. Elsewhere, Christians are exalted compared to the Jews: 'They are among the righteous' (3: 113-115); yet, the basic dogmas of Christianity are explicitly denied. ${ }^{9}$ In addition, however, there are signs of a kind of pluralist tolerance in the claim that different religions coexist and that their multiplicity is caused both by the will of man and God. For God, although he could have formed a single community of Islamic nations (ummah), he has in fact admitted the multitude of religions until the day of the Last Judgment, in which he gathers all around him, clarifies everything, and concludes contradictions and disputes. After all, he is the only God of all - 'our God and your God is one [and the same]' (29:46). Therefore, nobody can be forced into one faith. Believers of various religions should compete in good deeds. ${ }^{10}$

9 These facts are repeatedly highlighted by Samir Khalil Samir, e.g. in ID, Violence et Non-violence dans le Coran et l'Islam (Beyrouth: CEDRAC, 2005); Samir Khalil Samir S.J., 'Giovanni Paolo II e i musulmani,' Asia News, last modified 30 April 2011, https:// cutt.ly/blS3GaM.; Samir Khalil Samir S.J., 'Giovanni Paolo II e i musulmani II,' Asia News, last modified 2 May 2011, https://cutt.ly/4IS8OCI.; Samir Khalil Samir S.J., 'Giovanni Paolo II e i musulmani III,' Asia News, last modified 5 May 2011, https:// cutt.ly/hlS3gtj.; Samir Khalil Samir S.J., 'Benedetto XVI e l'Islam,' Asia News, last modified 26 April 2006, https://cutt.ly/2IS4FZZ.; Samir Khalil Samir S.J., 'Papa Francesco e l'invito al dialogo con l'Islam,' Asia News, last modified 19 December 2013, https:// cutt.ly/xlS4V8w.; Samir Khalil Samir S.J., 'La nuova legge anti-discriminazione è un passo avanti nella libertà religiosa,' Asia News, last modified 27 July 2015, https://cutt .ly/WIS7h49.; Samir Khalil Samir S.J., 'Sinodo: cristiani e islam, esigere la libertà religiosa, combattere l'estremismo,' Asia News, last modified 19 October 2010, https://cutt .ly/tlS73KB.; Samir Khalil Samir S.J., 'Cristiani e musulmani: vivere insieme con Gesù diversi,' Asia News, last modified 1 April 2008, https://cutt.ly/RIS5g3i.; Samir Khalil Samir S.J., 'Limprobabile dialogo di Benedetto XVI con i 138 saggi musulmani,' Asia News, last modified 9 January 2008, https://cutt.ly/llS5SeV.

Different approach is presented by other authors, e. g. Klaus von Stosch, 'Gewalttexte in Bibel und Koran.' IKaZ Communio 46, no. 2 (2017): 140-149; Emmanuel Pisani, 'La violence dans le Coran,' Croire - La Croix, last modified 12 June 2015, https://cutt.ly /qlS688Y., etc.

10 'O faithless ones! I do not worship what you worship, nor do you worship what I worship; nor will I worship what you have worshiped. To you your religion, and to me my religion' (109). 'We sent down the Torah containing guidance and light. [...] And We followed them with Jesus son of Mary, to confirm that which was before him of the Torah, and We gave him the Evangel containing guidance and light, confirming what was before it of the Torah, and as guidance and advice for the Godwary. We have sent down to you the Book with the truth, confirming what was before it of the Book and as a guardian over it. So judge between them by what Allah has sent down, and do not follow their desires against the truth that has come to you. For each [community] among you We had appointed a code [of law] and a path, and had Allah wished He would have made you one community, but [His purposes required] that He should test you in respect to what He has given you. So take the lead in all good works. To Allah shall be 
From the above-said, the following statements can be deduced: The Quran admits a plurality of religions wanted by God, i.e. revealed religions, meaning Judaism, Christianity, and Islam; these religions or rather revelations are placed in the sequence of history and truth by claiming that Christianity corrects the deviations of Judaism and the deviations of Christianity are corrected by Islam, which is, therefore, the ultimate, truest, and decisive religion; it is also a reason of a certain tolerance for those religions and for the idea that 'our God and your God is one and the same' although alongside the idea that 'with Allah religion is Isläm', which may also lead to the promotion of its domination.

It can be argued that all these texts are only about the relationship between the monotheistic Abrahamic religions and that the relationship between Islam and other religions is even more complicated. Its tolerance does not include equality of different religions but takes the form of legally protected enclaves (dhimma) of Jews or Christians within the majority rule of Islam. In light of this, there is a question how contemporary Muslims actually understand the general, universal validity of the document, which takes into account the plurality of religions as wanted by God and is defined as an invitation to reconciliation and fraternity not only 'among all believers' but also 'among believers and non-believers, and among all people of good will'. However, we will no longer investigate this point.

the return of you all, whereat He will inform you concerning that about which you used to differ.' (5:44-48). 'And had your Lord wished, all those who are on earth would have believed. Would you then force people until they become faithful? No soul may have faith except by Allah's leave, and He lays defilement on those who do not apply reason. [...] And follow that which is revealed to you, and be patient until Allah issues [His] judgement, and He is the best of judges' (10:99-100,109). 'Had your Lord wished, He would have made mankind one community; but they continue to differ. [...] And say to those who do not have faith, Act according to your ability; we too are acting. And wait! We too are waiting' (11:118,121). 'Say, Will you argue with us concerning Allah, while He is our Lord and your Lord, and our deeds belong to us, and your deeds belong to you, and we worship Him dedicatedly?' (2:139). 'I believe in whatever Book Allah has sent down. I have been commanded to do justice among you. Allah is our Lord and your Lord. Our deeds belong to us and your deeds belong to you. There is no argument between us and you. Allah will bring us together and toward Him is the destination' (42:15). 'Do not dispute with the People of the Book except in a manner which is best, barring such of them as are wrongdoers, and say, We believe in that which has been sent down to us and has been sent down to you; our God and your God is one [and the same], and to Him do we submit' (29:46). 'And say, [This is] the truth from your Lord: let anyone who wishes believe it, and let anyone who wishes disbelieve it.' (18:29). 'There is no compulsion in religion: rectitude has become distinct from error' $(2: 256)$. 
Suffice it to say that if the document states that 'God has created us to understand one another, cooperate with one another and live as brothers and sisters who love one another', it paraphrases the verse of the Quran where it says, 'O mankind! Indeed We created you from a male and a female, and made you nations and tribes that you may identify yourselves with one another. Indeed, the noblest of you in the sight of Allah is the most Godwary among you. Indeed, Allah is all-knowing, all-aware' (49:13). The work with this verse and the overall message of the document is a manifestation of the will on the Muslim side to choose such an interpretation of the Quran, which would help - as the last words of the text say - to achieve 'a universal peace that all can enjoy in this life'.

\section{Compliance with Christianity?}

\subsection{Only Christianity Is from God}

The lack of considerations similar to those we have presented above has burdened critical commentaries of the document, which came from the Catholic side immediately after its signing. Their origin was mainly from the Church's right flank (Raymond Leo Burke, Nicola Bux, Roberto de Mattei, Davide Pagliarani, Josef Seifert, Athanasius Schneider, Carlo Maria Viganò, Thomas G. Weinanda, etc.), which is not surprising since the liberal left is not so much concerned with the tradition or dogma so the possible discrepancy between the Abu Dhabi document and the Christian faith would not be so much disturbing for them.

In particular, two topics were criticised:

The first of these is the phrase 'our common belief in God', into which the basic premise of the document is inserted. It was contrasted with the statement of the Congregation for the Doctrine of the Faith in the declaration Dominus Iesus, which states that it is vital to maintain the distinction between the theological faith (fides theologalis), which is a gift of grace and answers to the self-revelation of the Triune God, and the beliefs (credulitas) of other religions, which are the sum of human experience, reflection, and religiosity in relation to the Divine and the Absolute. This distinction expresses and underlines the difference between Christianity and other religions. ${ }^{11}$ After all, the erroneous

11 Congregation for the Doctrine of the Faith, Joseph Ratzinger, 'Declaratio Dominus Iesus de Iesu Christi atque Ecclesiae unicitate et universalitate salvifica,', La Santa 
teaching of the Abu Dhabi declaration is refuted by the infallible teachings of the First Vatican Council, which in the doctrinal constitution Dei Filius stated that 'there is no parity between the condition of those who have adhered to the Catholic truth by the heavenly gift of faith, and the condition of those who, led by human opinions, follow a false religion' (chap. 3 and can. 6). ${ }^{12}$ And there is a significant notification from the Congregation for the Doctrine of the Faith in the case of Jacques Dupuis SJ. ${ }^{13}$

The second criticised topic is the studied passage on the plurality of religions according to God's will, which is commented in the following indignant way: Pope Francis denied Jesus Christ. He has committed ungodliness and heresy because he attributes to God the positive will that there should be religions that contradict the Revelation and are adversarial, erroneous, and untrue, and even extremely cruel. Does God want people to confess the contradictory facts about himself? Does he want people to worship false gods, be followers of atheistic or pantheistic religions, or worship demons? Does he want religions with human sacrifices or worshipping a golden calf? Does he want religions that deny the divinity, crucifixion, and resurrection of Jesus Christ? The Pope denied God's plan of salvation, according to which Jesus Christ crucified is the only Saviour and the incarnate truth of God. The document is based on the Islamic image of God: it does not mention the Trinity or Christ, and therefore the Pope did not confess the only Name in which people can be saved. After all, the document

Sede, last modified 6 August 2000, https://cutt.ly/IIDqVL6.: 'For this reason, the distinction between theological faith and belief in the other religions, must be firmly held. If faith is the acceptance in grace of revealed truth, which "makes it possible to penetrate the mystery in a way that allows us to understand it coherently", then belief, in the other religions, is that sum of experience and thought that constitutes the human treasury of wisdom and religious aspiration, which man in his search for truth has conceived and acted upon in his relationship to God and the Absolute. This distinction is not always borne in mind in current theological reflection. Thus, theological faith (the acceptance of the truth revealed by the One and Triune God) is often identified with belief in other religions, which is religious experience still in search of the absolute truth and still lacking assent to God who reveals himself. This is one of the reasons why the differences between Christianity and the other religions tend to be reduced at times to the point of disappearance.'

12 Diane Montagna, 'Interview on "Fratelli Tutti" with Bishop Athanasius Schneider,' The Remnant, last modified 14 October 2020, https://cutt.ly/7IDkQrF.

13 Congregation for the Doctrine of the Faith. Joseph Ratzinger, 'Notification on the book Toward a Christian Theology of Religious Pluralism (Orbis Books: Maryknoll, New York 1997) by Father Jacques Dupuis, S.J,' La Santa Sede, last modified 24 January 2001, https://cutt.ly/JIDkD1h. 
does not even speak of sin, conversion, and salvation. Peter's successor thus resigned to the claim that Christianity is the religio vera that brings people a supernatural life with the Triune God. He devaluates the sacrifices of martyrs, who could actually be content with the fact that even pagan religions corresponded to God's will. He also implicitly acknowledged that God wanted a plurality of Christian denominations, thus denying Jesus' prayer that everyone should be one. He professed a fraternity without Christ and without the Church, outside which there is no salvation. He chose a purely humanistic conception of fraternity and became the protagonist of the Masonic united world religion. The relevant statement should, therefore, be removed as incorrect. More precisely, Pope Francis should publicly recall it. If he does not do so, the canon of the Code of Canon Law, according to which the Pope loses his Peter's office if he professes heresy, will be applied. And this is the sum of all heresies. After all, with this declaration, the Pope himself renounced the task of strengthening the brothers in faith in Christ. ${ }^{14}$

\subsection{Religiosity Comes from God, Not the Plurality of Religions}

Alongside these reactions, which accused the Pope of extremely serious offences, others were trying to defend him. For example, according to Thomas Petri OP, the relevant passage intended to express that, just

14 'Bergoglio firma documento musulmano rinnegando Gesù Cristo,' Le Croniche di apa Francesco, last modified 4. February 2019, https://cutt.ly/sIDIR3h.; Mic, 'Una pace che rinnega Cristo e la nostra Fede,' Blogger, last modified 4 January 2019, https:// cutt.ly/EIDzc4m.; Thomas G. Weinandy, 'Pope Francis, the uniqueness of Christ, and the will of the Father,' The Catholic World Report, last modified 2 June 2019, https:// cutt.ly/YIDz7YN.; Edward Pentin. 'Does the New Catholic-Muslim Declaration Deviate From Catholic Teaching?'’ National Catholic Register, last modified 15 February 2019, https://cutt.ly/IWJ9Pak; Aldo Maria Valli, 'Questa crisi viene da molto lontano,' Aldo Maria Valli, last modified 3 February 2019, https://cutt.ly/kIDxArs.; ID. Roberto de Mattei, 'Il più terribile scisma che il mondo abbia mai visto,' Corrispondenza Romana, last modified 1 May 2019, https://cutt.ly/ylDvwOk.; Aldo Maria Valli - Nicola Bux, 'Ma se togliamo la Croce di Cristo non ci resta che il deismo (massonico),' Aldo Maria Val$l i$, last modified 11 February 2019, https://cutt.ly/IlDvYty.; Davide Pagliarani, 'Comunicato del Superiore generale della FSSPX: La vera fratellanza esiste solo in Gesù Cristo,' FSSPX, last modified 24 February 2019, https://cutt.ly/pIDvMJH.; Josef Seifert, 'Grave Concerns About Pope Francis' Abu Dhabi Document,' en.news, last modified 8 February 2019, https://cutt.ly/clDbdfk.; Athanasius Schneider, 'Il cristianesimo è l'unica religione voluta da Dio,' Stilvm Cvriae, last modified 8 February 2019, https://cutt.ly /gIDnwNC.; ID, 'There is no divine positive will or natural right to the diversity of religions,' Life Site, lastmodified 1 June 2020, https://cutt.ly/ZIDnBvK.; Marco Tosatti, 'Il papa minaccia la sopravvivenza della chiesa cattolica,' Stilvm Cvria, last modified 22 November 2019, https://cutt.ly/TWJ3qtz; Steve Skojec, 'Vatican II marked the beginning of a false, parallel Church,' One Peter 5, last modified 9 June 2020, https://cutt.ly/rlDmKBP. 
as God created us with a specific colour of skin, gender, and language, he also created us with a desire to know transcendence and worship the highest divine power, i.e. with a disposition to the virtue of religiosity. ${ }^{15}$ Alfredo Morselli then provided a more detailed interpretation in the same line: God tilts all people toward himself as their goal and thus wants them to be religious. They get to know the existence of God and are obliged to express their relationship to him in the form of a cult even without supernatural Revelation. They have to do everything they are able to do. And those who do so are not denied God's grace (facienti quod in se est Deus non denegat gratiam: Thomas Aquinas, In II Sent. d. 28, q. 1, a. 4 ad 4); although without their own guilt they are not Christians, they can be viewed as having 'implicit faith' (fides implicita: Thomas Aquinas, STh II-II, q. 10, a. 4 ad 3) in that God who revealed himself in Jesus Christ and who established fellowship between people and himself in the Catholic Church. The material minimum of the believed content, which is associated with incompleteness and error, corresponds to the formal maximum of an act of faith. Such a person may not be aware that he or she is wrong and therefore does not have to have any guilt. However, it is only this inclination to religion (respectively, the religious act), which comes from God, not a false religion as such. This, like sin, comes from God insofar as it is a being and an act; but God is not the cause of the fact that the act is defective (Thomas Aquinas, STh I-II, q. 79, a. 2 co. and ad 2). Man is, together with God, the cause of the act, but only man is the cause of its defect. Therefore, it cannot be said that God wants religious plurality. He wants and causes human religiosity, not its defect. ${ }^{16}$

15 Edward Pentin, 'Does the New Catholic-Muslim Declaration Deviate From Catholic Teaching?,' National Catholic Register, last modified 15 February 2019, https://cutt.ly /GIDQhWx.: 'St. Thomas Aquinas says that religion is almost like a virtue that everyone should acquire, whether believer or not [...]. And by that, he simply means the desire to worship a higher power, a desire to seek that which is beyond. I suspect that's what the Holy Father is getting at, [...] that just like our skin color, just like our sex, just like our language, God created us with this desire to know the transcendent, to know the divine, and we believe and have always believed that the answer to that desire is Jesus Christ who is incarnate.'

The natural desire to know God has been also pointed out by Chad Pecknold: Diane Montagna, 'Pope Francis under fire for claiming "diversity of religions" is "willed by God", Life Site, last modified 5 February 2019, https://cutt.ly/RIDQDOR.

16 Alfredo Morselli, 'Il pluralismo e la diversità di religione sono voluti da Dio nella sua sapienza?,' Cooperatores Veritatis, last modified 17 February 2019, https://cutt.ly /LIDQ6GR. 
In this respect, the Second Vatican Council's claim in the doctrinal constitution Lumen Gentium 16, according to which Muslims worship God together with Christians (nobiscum Deum adorant), seems to be very theologically problematic. Thanks to their natural act of religiosity and the natural knowledge of the Creator, non-Christians who sincerely worship God, the Creator, worship the same God whom the Christians worship with supernatural faith and supernatural knowledge as the Triune. However, it is true that 'the acts of adoration, and the acts of knowing on which they are based, are substantially different, though the object is the same in that it is the same God.' The list of differences in the knowledge of God and God's actions is, therefore, extensive. ${ }^{17}$

\subsection{God Does Not Want the Plurality of Religions but Admits It}

It was the commentary by Father Z., i.e. John Zuhlsdorf, published the day after the signature of the document, which played a crucial role in its Catholic interpretation. He said that, when we speak of God's will, we must distinguish between 'active and positive will', which is what is good, true, and beautiful, and 'permissive will', which allows happening something which is not in accordance with an order established by God himself. If we read the document from Abu Dhabi in the light of God's positive will, then it would be true that he would place the positive values (differences in skin colour, gender, race, and language) on the same level with something that should not be positive in itself, namely plurality and differences of religions: the plurality implies that some people believe false things, so the same God, who wants all people to be saved and to know the truth, should also want people to believe in other things than the truth itself. However, if we read the document in the light of God's permissive will, it would be - Father Z. said - acceptable because then it would not say that God wants the diversity in religions in the sense that they are all the same, equal paths to God. False religions are evil, and God does not actively want evil, he only allows it to achieve some greater good. ${ }^{18}$

17 Athanasius Schneider, 'Catholics and Muslims share no common faith in God, no common adoration,' Corrisopndenza Romana, last modified 8 June 2020, https://cutt .ly/ilDWO8s.

18 John Zuhlsdorf, 'Francis signed document saying that God willed the "pluralism and diversity of religions". What's up with that?,' Twitter, last modified 5 February 2019, https://cutt.ly/JIDEsYD.: 'God did not will a diversity of religions in the sense that all religions are equal paths to God. False religions are evil. God does not actively will evil. When we speak of God's will we make distinctions. God has an "active or positive 
This is exactly the argument that Pope Francis himself adopted. On the way from Abu Dhabi, he defended the document by saying that, from the Catholic point of view, he 'did not deviate by even a millimeter from the Second Vatican Council' and was, on the contrary, drafted 'in the spirit' of this council, which is thus being further developed. ${ }^{19}$ On 3 April 2019, he returned to the relevant passage of the document during the general audience, saying:

[W]hy does God allow many religions? God wanted to allow this: Scolastica theologians used to refer to God's voluntas permissiva. He wanted to allow this reality: there are many religions. Some are born from culture, but they always look to heaven; they look to God. But what God wants is fraternity among us and in a special way [...] with our brothers, Abraham's children like us, the Muslims. We must not fear differences. God allowed this. We should be afraid were we to fail to work fraternally to walk together in life. ${ }^{20}$

The Pope allegedly confirmed this position in contact with Bishop Athanasius Schneider. He was said to have acknowledged that the sentence could be misunderstood because even if the plurality of religion was the subject of God's voluntas permissiva, the same is no longer the case, for example, with the plurality of sex which God wants directly and positively. Schneider adds that the only religion God desires is the faith in Jesus Christ, and demands that the Pope publicly revoke or correct his statement. However, Francis did not do anything like that and did not even publish what Schneider quoted from the interview anywhere. The Catholic right flank, therefore, repeats that plurality and diversity of religions is a moral evil that God admits but is not the

will" and a "permissive will". God's "active will" concerns that which is good, true and beautiful. On the other hand, God has a "permissive will" by which He allows that things will take place that are not in accord with the order He established. [...] Read in this way, namely, that by God's permissive will there are a multiplicity of religions, etc., that statement in the document, above, is acceptable. If you read the statement to mean that by God's positive or active will there are a multiplicity of religions, that's an error. That would impute to God the active willing of false religions and, therefore, evil, which is impossible and contrary to reason. God cannot positively will evil. God can only, by His nature, permissively will evil. I don't know what the writers of the document intended. I'm just telling the truth about what is written.' Pope Francis, 'Conferenza Stampa del Santo Padre sul volo di ritorno da Abu Dhabi,' La Santa Sede, last modified 5 February 2019, https://cutt.ly/elDE1gB.

20 Pope Francis, 'Udienza Generale: Catechesi sul Viaggio Apostolico in Marocco,' La Santa Sedete, last modified 3 April 2019, https://cutt.ly/7IDRiqC. 
result of his positive will. His will is that all people receive faith in Jesus Christ and are saved in him through the fellowship with the Catholic Church. God simply did not prevent the existence of other religions to derive another good from it, which is to encourage Christians to grow in their faith and develop their missionary love. ${ }^{21}$

\subsection{The Plurality of Religions Belongs to God's Providence}

The Jesuit Domenico Marafioti proceeded further than the above-cited authors, stating that the pluralism of religions probably does not belong to God's original purpose for creation, but rather to God's leading of man through the history. That is why he also suggested reading the key sentence of the declaration as if it said: the plurality and differences of religions 'are the result of the wise decision of the divine will with which God created and led man in the history'. However, this does not belong to a pre-lapse reality (Gen. 1-2) but to a post-lapse reality (Gen. 3). In history, which is burdened with guilt, the Providence leads humanity temporarily also through religious pluralism. 'In the past, he let all nations go their own way' (Acts 14:16), and this includes religious pluralism as a manifestation of the common experience of the sacred and its interpretation according to its intellectual and cultural categories. $^{22}$

However, it can be objected against Marafioti that these speculations about God's will as such, regardless of his salvific historical will, are inappropriate, as the Cardinal Gerhard Ludwig Müller, the former prefect of the Congregation for the Doctrine of the Faith, pointed out in this context. In other words, there has never been any other will of God about his rational creatures than the desire for their eternal salvation in the Church of Christ and its gradual realisation in the history: 'His providence, His manifestations of goodness, His saving design extend to all men, until that time when the elect will be united in the Holy City,

21 Diane Montagna and Athanasius Schneider, 'Bishop Schneider wins clarification on "diversity of religions" from Pope Francis, brands abuse summit a "failure",' Life Site, last modified 7 March 2019, https://cutt.ly/ilDRvgs.; Maike Hickson and Athanasius Schneider, 'Pope must formally correct statement that God wills false religions,' Life Site, last modified 8 May 2019, https://cutt.ly/FIDRSZy.; Roberto de Mattei. 'Che cos'è la "volontà permissiva” di Dio,' adici Cristiane, accessed 29 February 2020, https:// cutt.ly/xIDRBbp.; Alfredo Morselli, 'La voluntas permissiva di Dio e il Documento di Abu Dhabi: Quando la toppa è peggio del buco,' Cooperatores Veritatis, last modified 7 April 2019, https://cutt.ly/5IDTdhD.

22 Domenico Marafioti, 'Documento sulla Fratellanza umana'. 
the city ablaze with the glory of God, where the nations will walk in His light' (Nostra aetate 1).

Müller, therefore, described the plurality of religions as a positive manifestation of the Providence. ${ }^{23}$ Individual specific religions despite all their shortcomings in details - have a role to play in God's plan of salvation, in which God manifests himself as the Creator and Goal, who ultimately wants to unite humanity in communion with himself. On the one hand, they are the ways of realising the natural effort of reason to know God and to be in blissful communion with him. Each person is directed towards God, and this focus is manifested in natural religiosity as well as by a historically conditioned (i.e. in concrete time, society, and culture) belonging to a specific religious community. On the other hand, these religions are a manifestation of God's Providence, which in time and with a view to eternity promotes a universal vocation to salvation in Christ: not always with an explicit personal faith in him, but always through the incarnate Son and through his Church as the sacrament of salvation (Lumen gentium 1; 45; Gaudium et spes 48).

This does not mean that all religions - in the plurality of their forms - are in themselves ways of salvation, nor that God simply admits them as a kind of allowed evil, but that God actively wants everything which is true, good, and beautiful in them as the preparation to the salvation of man in the encounter with Christ, whether it occurs in time explicitly or at least implicitly by acting according to the known truth. Precisely because of what 'is true and holy in these religions', they can be regarded from a Christian perspective as often reflecting 'a ray of that Truth which enlightens all men' (Nostra aetate 2). They are the 'seeds of the Word', which is like a good seed sown in human hearts and minds or in the rites and cultures of nations (Ad gentes 11; Lumen gentium 17). In our case, it means: 'What God certainly does not want in Islam is the denial of the Trinity, the incarnation, the divine sonship of Christ, and the redemption of mankind from sin through him,' as Müller points out. However, with regard to the universal saving will, it can be said that God wants a Muslim to profess the one God and Creator, who is omnipotent and merciful to all, he wants him to believe in

23 Gerhard L. Müller, 'Das Abu Dhabi Dokument: Eine katholische Lesehilfe,' IkZ Communio 49, no. 3 (2020): 293-311. 
the judgment of good and evil deeds and to expect an afterlife in heaven or hell (Nostra aetate 3; Lumen gentium 16). ${ }^{24}$

\section{Conclusion}

As concerns our commentary on the passage from the 'Document on Human Fraternity', the foregoing considerations demonstrate that it is not a doctrinal statement of the papal Magisterium and may not be a statement which is, standing alone, entirely coherent with the Christian faith; however, it cannot contradict this faith and has to be interpreted to have a positive meaning from the point of view of the whole Catholic faith, while supporting the interpretation which helps to realise the common intentions of the document.

It was further clarified that the passage quoted in the document echoes anti-discrimination human rights declarations, which list the criteria according to which people cannot be discriminated; nevertheless, the document turns their negative diction into a positive wording explaining the existence of these differences as a consequence of God's creative wisdom.

In terms of the genesis and the redaction of the text, this could be an echo of the fact that the Quran admits a plurality of religions wanted by God (Judaism, Christianity, and Islam), which results in a certain tolerance of Judaism and Christianity (not their equality with Islam) and a basic openness to the principle of freedom of religion.

From the Christian point of view, which is based on the confession that Jesus Christ is - in his Church - the only mediator of salvation for all people, the commented statement was accepted with hesitation. Some commented that the Pope had committed ungodliness and heresy because he attributes to God a positive will to welcome religions that deny the uniqueness of Jesus Christ and that are contradictory, erroneous, and untrue. The next approach claims that Christians should understand the document in the sense that God's creative will has inserted natural religiosity in all human beings, which, however, does not mean that he also positively wants a plurality of religions as all non-Christian religions are actually evil and God never actively wants

24 Armin Schwibach and Gerhard L. Müller, 'Die "heißen Themen" zwischen den Jahren 2019 und 2020,' Katholische Nachrichten, last modified 23 December 2019, https://cutt.ly/4IDTYqg. 
evil; he only allows it to achieve some greater good, which is to encourage Christians to grow in their faith and to their missionary love. A more open interpretation stated that all religions are the manifestations of natural religiosity, and they are actively wanted by God's Providence as a preparation for the salvation of man in the encounter with Christ in what is true, good, and beautiful in them.

However, it is possible to go a little further if we look at the commented statement of the 'Document on Human Fraternity' through the prism of the catechesis of John Paul II from 9 September 1998, in which he pointed out that every openness of the human spirit to truth and good, and ultimately to God, is awakened by the Holy Spirit, and that it is the origin of various non-biblical religions. In their beginnings, we often find founders who, with the help of the Holy Spirit, made a deeper religious experience, which was then passed on to other people by taking on the form of doctrines, ceremonies, and commandments of various religions. By practising what is true and good in them, and by showing love to others, these pious people, in the power of God's Spirit, respond positively to God's invitation to salvation in Jesus Christ and participate in his Easter sacrifice. ${ }^{25}$

25 'It must first be kept in mind that every quest of the human spirit for truth and goodness, and in the last analysis for God, is inspired by the Holy Spirit. The various religions arose precisely from this primordial human openness to God. At their origins we often find founders who, with the help of God's Spirit, achieved a deeper religious experience. Handed on to others, this experience took form in the doctrines, rites and precepts of the various religions. [...] "The Spirit's presence and activity", as I wrote in the Encyclical Letter Redemptoris missio, "affect not only individuals but also society and history, peoples, cultures and religions" (n. 28). Normally, "it will be in the sincere practice of what is good in their own religious traditions and by following the dictates of their own conscience that the members of other religions respond positively to God's invitation and receive salvation in Jesus Christ, even while they do not recognize or acknowledge him as their Saviour (cf. Ad gentes 3, 9, 11)". Indeed, as the Second Vatican Council teaches, "since Christ died for all, and since all men are in fact called to one and the same destiny, which is divine, we must hold that the Holy Spirit offers to all the possibility of coming into contact, in a way known to God, with the paschal mystery" (Gaudium et spes 22). This possibility is achieved through sincere, inward adherence to the Truth, generous self-giving to one's neighbour and the search for the Absolute inspired by the Spirit of God. A ray of the divine Wisdom is also shown through the fulfilment of the precepts and practices that conform to the moral law and to authentic religious sense. Precisely by virtue of the Spirit's presence and action, the good elements found in the various religions mysteriously prepare hearts to receive the full revelation of God in Christ.,' John Paul II., 'General audience,' La Santa Sede, last modified 9 September 1998, https://cutt.ly/EIDYWiA. Quotation from Pontifical Council for Interreligious Dialogue and Congregation for the Evangelization of Peoples, 'Instruction Dialogue and Proclamation' (19.05.1991), 29. 
God created the world 'so that [people] would seek him and perhaps reach out for him and find him' (Acts 17:27), and 'to those who by persistence in doing good seek glory, honor and immortality, he will give eternal life' (Rom. 2:7). This search, the manifestation of natural religiosity, is the cause of the existence of various historical forms of religions, which, in what is authentic in them, are caused by the Spirit of God, who leads these believers to meet Jesus Christ in his Church or rather in the final space of salvation, which is the heavenly Jerusalem. It is, from God's Providence, a paedagogia ad Deum verum and praeparatio evangelica. ${ }^{26}$

Catholic Theological Faculty, Charles University

Thákurova 3

16000 Praha 6

Czech Republic

E-mail: vojtech.novotny@ktf.cuni.cz

26 Second Vatican Council, Ad gentes 3: 'This universal design of God for the salvation of the human race is carried out not only, as it were, secretly in the soul of a man, or by the attempts (even religious ones by which in diverse ways it seeks after God) if perchance it may contact Him or find Him, though He be not far from anyone of us (cf. Acts 17,27). For these attempts need to be enlightened and healed; even though, through the kindly workings of Divine Providence, they may sometimes serve as leading strings toward God, or as a preparation for the Gospel.' 